\title{
Effects of Carbonation on Mechanical Properties and Durability of Concrete Using Accelerated Testing Method
}

Jack M. Chi

Ph.D. Candidate, Department of Harbor and River Engineering, National Taiwan Ocean University, Keelung, Taiwan, R.O.C.

Ran Huang

Professor, Department of Harbor and River Engineering, National Taiwan Ocean University, Keelung, Taiwan, R.O.C.

C. C. Yang

Professor, Institute of Materials Engineering, National Taiwan Ocean University, Keelung, Taiwan, R.O.C.

Follow this and additional works at: https://jmstt.ntou.edu.tw/journal

Part of the Civil and Environmental Engineering Commons

\section{Recommended Citation}

Chi, Jack M.; Huang, Ran; and Yang, C. C. (2002) "Effects of Carbonation on Mechanical Properties and Durability of Concrete Using Accelerated Testing Method," Journal of Marine Science and Technology. Vol. 10: Iss. 1, Article 3. DOI: $10.51400 / 2709-6998.2296$

Available at: https://jmstt.ntou.edu.tw/journal/vol10/iss1/3

This Research Article is brought to you for free and open access by Journal of Marine Science and Technology. It has been accepted for inclusion in Journal of Marine Science and Technology by an authorized editor of Journal of Marine Science and Technology. 


\title{
EFFECTS OF CARBONATION ON MECHANICAL PROPERTIES AND DURABILITY OF CONCRETE USING ACCELERATED TESTING METHOD
}

\author{
Jack M. Chi*, Ran Huang**, and C. C. Yang***
}

Key words: Carbonation, durability, accelerated testing method.

\section{ABSTRACT}

An experimental investigation was carried out to study the effect of carbonation on mechanical properties and durability of concrete. Ordinary portland concretes (OPC) with water/cement ratios of 0.58 and 0.48 and self-compacting concretes (SCC) with water/binder ratios of 0.40 and 0.36 were used in this study. Compressive strength test, splitting strength test, electrical resistivity test, rapid chloride penetration test (RCPT), open circuit potential method and alternative current (AC) impedance method were performed to estimate the properties of concrete. Test results showed that carbonation may compensate some concrete properties such as compressive strength, splitting strength, electrical resistivity and chloride ion penetration. However, corrosion test results showed that carbonation increases corrosion rate of reinforcing steel.

\section{INTRODUCTION}

Durability is a major concern for concrete structures exposed to aggressive environments. Many environmental phenomena are known to significantly influence the durability of reinforced concrete structures [13]. Carbonation is one of the major factors to cause structure deterioration. Carbonation is the reaction of the hydration products dissolved in the pore water with the carbon dioxide in the air which reduces the $\mathrm{pH}$ of concrete pore solution from 12.6 to less than 9 and steel passive oxide film may be destroyed and accelerating uniform corrosion [4]. Carbonation-induced corrosion can increase crack development and decrease concrete durability [5].

Carbonation reduces $\mathrm{pH}$ value and destroys the passive film around the steel, but it seems to densify

Paper Received Oct. 15, 2001. Author for Correspondence: Jack M. Chi. *Ph.D. Candidate, Department of Harbor and River Engineering, National Taiwan Ocean University, Keelung, Taiwan, R.O.C.

**Professor, Department of Harbor and River Engineering, National Taiwan Ocean University, Keelung, Taiwan, R.O.C.

***Professor, Institute of Materials Engineering, National Taiwan Ocean University, Keelung, Taiwan, R.O.C. concrete surface and reduce chloride ion permeability, reduce surface porosity and hence sorptivity in concrete [6-8]. Carbonation could have both positive and negative effects on concrete durability. Glass et al. pointed out that the presence of even a small amount of chloride in carbonated concrete enhances the corrosion rate resulted from carbonation of concrete [9].

The basic factor influencing carbonation is the diffusivity of the hardened cement paste. Carbonation rate is controlled by the ingress of $\mathrm{CO}_{2}$ into concrete pore system by diffusion with a concentration gradient of $\mathrm{CO}_{2}$ acting as the driving force. Factors affecting diffusion rate include the type and amount of cement, porosity of the material, time of curing, type and quantity of pozzolanic additions [3,10]. Moreover, several mechanical properties of concrete such as compressive strength, surface hardness and resistance to aggressive agents may change due to carbonation [6]. In this paper, compressive strength test, splitting strength test, electrical resistivity test, rapid chloride penetration test (RCPT), open circuit potential method and alternative current (AC) impedance method were performed to study the effect of carbonation on mechanical properties and durability of concrete.

\section{EXPERIMENTAL PROGRAM}

\section{Materials}

Type I portland cement with a specific gravity of 3.15 and fineness of $330 \mathrm{~m}^{2} / \mathrm{kg}$ was used in all mixtures. Blast furnace slag with a specific gravity of $2.90( \pm 0.01)$ and the surface area of $383 \mathrm{~m}^{2} / \mathrm{kg}$ was used. The chemical compositions of cement and blast furnace slag expressed in percentage by weight of the constituent oxides are shown in Table 1 . The coarse aggregate with a size range of $6 \sim 25 \mathrm{~mm}$ was used The fine aggregate was river sand with a maximum size of $4 \mathrm{~mm}$ and fineness modulus of 2.72. Type F superplasticizer (SP) with a specific gravity of $1.2( \pm 0.01)$ was used. The $\mathrm{pH}$ is $8.0 \sim 9.0$ and the content of chloride ion is less than 
$1000 \mathrm{ppm}$.

\section{Mixing and Preparation of Specimens}

Two groups of concrete mixtures-ordinary portland concrete (OPC) with water/binder ratios of 0.58 and 0.48 (N58 and N48) and self-compacting concrete (SCC) with water/binder ratios of 0.40 and 0.36 (S40 and S36) were designed and tested. Water/binder ratio was defined as the weights of water and superplasticizer divided by the weights of cement and slag. Details of mix proportions are given in Table 2 . In this study, selfcompacting concrete (SCC) is defined as a concrete that has a slump $\geq 23 \mathrm{~cm}$, a slump flow $\geq 60 \mathrm{~cm}$, and a filling height $\geq 30 \mathrm{~cm}$ in box test. During the first 24 hours the specimens were left in the molds and cured in water until the time of testing. Concrete specimens $(100 \times 200$ $\mathrm{mm}$ ) sealed on both top and bottom surface were prepared. Three $\mathrm{CO}_{2}$ concentration levels of $50 \%, 75 \%$ and $100 \%$, respectively, were chosen to accelerate carbonation test and compare the effect of carbonation on mechanical properties and durability of concrete. Testing temperature was kept at $23^{\circ} \mathrm{C}$ and relative humidity is $70 \%$. Let $\mathrm{A}, \mathrm{B}$ and $\mathrm{C}$ represent $\mathrm{CO}_{2}$ concentration of $50 \%, 75 \%$ and $100 \%$, respectively.

\section{Experimental Methods}

The flowability and workability of SCC were conducted by flow test, slump test, box test and V-funnel test. The slump test of concrete performed in accordance with ASTM C143. The compressive strength was determined according to ASTM C39. The splitting strength test was determined according to ASTM C469. An accelerated carbonation test was carried out according to the method designed by Papadakis et al. (1991) [11] and the phenolphthalein test for measuring carbonation depth was determined by RILEM CPC-18 [12].
Phenolphthalein is prepared as a $1 \%$ solution in $70 \%$ ethyl alcohol and the solution is sprayed onto the concrete surface which has been cleaned of dust and loose particles. Phenolphthalein is a colorless acid indicator which turns red when the $\mathrm{pH}$ is above a value of 9.5 , that is, when the concrete is alkaline. If no coloration occurs, carbonation has taken place and the depth of the carbonated surface layer can be measured. The rapid chloride penetration test (RCPT) was carried out following the standard ASTM C1202 (1997) [13]. Sodium hydroxide solution $(0.3 \mathrm{~N} \mathrm{NaOH})$ and sodium chloride solution ( $3 \% \mathrm{NaCl}$ by mass) were placed in the chambers on two sides of concrete specimen (100 mm diameter and $50 \mathrm{~mm}$ thickness), and a direct current voltage of $60 \mathrm{~V}$ was applied. The current passing through the concrete specimen was monitored every thirty minutes over a six-hour period and the total charge passed (Coulombs) was computed. The measurement of resistivity of concrete was obtained by the Wenner probes. The electrochemical corrosion test was performed using a three-electrode system. The variation of corrosion potential $\left(\Phi_{\text {corr. }}\right)$ with time were recorded with respect to a saturated calomel electrode (SCE) in stagnant solution at room temperature. Impedance measurements and data collection were made with a Impedance Gain-Phase Analyzer and a Nichia model Potentialstat. Impedance measurements were determined using a frequency scan from $1.0 \times 10^{6} \mathrm{~Hz}$ to $1.0 \times 10^{-3} \mathrm{~Hz}$ at a small overpotential $10 \sim 20 \mathrm{mV}$. When the polarization resistance was determined, the corrosion current density and the corrosion rate can be obtained by SternGeary's equation and Faraday's law, respectively.

\section{RESULTS AND DISCUSSIONS}

\section{Depth of Carbonation}

The carbonation depths were measured at the age

Table 1. Chemical composition of cement and blast furnace slag $(\%)$

\begin{tabular}{lcccccccc}
\hline & $\mathrm{CaO}$ & $\mathrm{SiO}_{2}$ & $\mathrm{Al}_{2} \mathrm{O}_{3}$ & $\mathrm{MgO}$ & $\mathrm{Na}_{2} \mathrm{O}$ & $\mathrm{K}_{2} \mathrm{O}$ & $\mathrm{SO}_{3}$ & $\mathrm{Fe}_{2} \mathrm{O}_{3}$ \\
\hline cement & 63.87 & 20.89 & 5.61 & 2.93 & - & - & - & 3.13 \\
blast furnace slag & 41.21 & 32.45 & 13.67 & 6.53 & - & - & 1.87 & 1.18 \\
\hline
\end{tabular}

Table 2. Mix proportions of concrete $\left(\mathrm{kg} / \mathrm{m}^{3}\right)$

\begin{tabular}{ccccrrrrr}
\hline mix No. & w/b & cement & water & slag & sand & aggregate & super-plasticizer & slump (cm) \\
\hline N58 & 0.58 & 350 & 203 & 0 & 735 & 1024 & 0 & 14 \\
N48 & 0.48 & 424 & 203 & 0 & 768 & 945 & 0 & 13 \\
S40 & 0.40 & 200 & 191 & 300 & 912 & 722 & 9.5 & 23.5 \\
S36 & 0.36 & 400 & 177 & 125 & 924 & 732 & 12.0 & 25 \\
\hline
\end{tabular}


of 7, 14, 21 and 28 days as shown in Figure 1. It can be seen that the carbonation depth increases with an increase of carbonation time and higher $\mathrm{CO} 2$ concentration has a higher carbonation depth for all mixtures. Concrete specimens of N58 and N48 show higher carbonation depths than those of S40 and S36. The rate of carbonation increases with an increase in $\mathrm{CO}_{2}$ concentration, especially for concrete specimens with higher water/binder ratios, the transport of taking place through the pore system in hardened cement paste [14]. Blast furnace slag addition results in lower carbonation depth because the pozzolanic reaction and filling effect are beneficial in minimizing the pore size and volumes, thus reducing the carbonation rate. However, the water/ binder ratio is still a key factor affecting the carbonation depth of concrete. And the carbonation depth increases in proportion to the square root of exposure time [5].

\section{Compressive Strength}

The compressive strengths for different water/ binder ratios of concrete specimens at the age of 7,14 and 28 days are presented in Figure 2. It shows that the compressive strength of carbonated concretes slightly increases in comparison with non-carbonated concretes. It is due to $\mathrm{CaCO}_{3}$ occupies a greater volume than $\mathrm{Ca}$ $(\mathrm{OH})_{2}$, the surface porosity of carbonated concrete is reduced. The relationship between carbonation depth and the compressive strength for various concretes with $100 \% \mathrm{CO}_{2}$ concentration at the age of 28 days is shown in Figure 3. It shows that the depth of carbonation

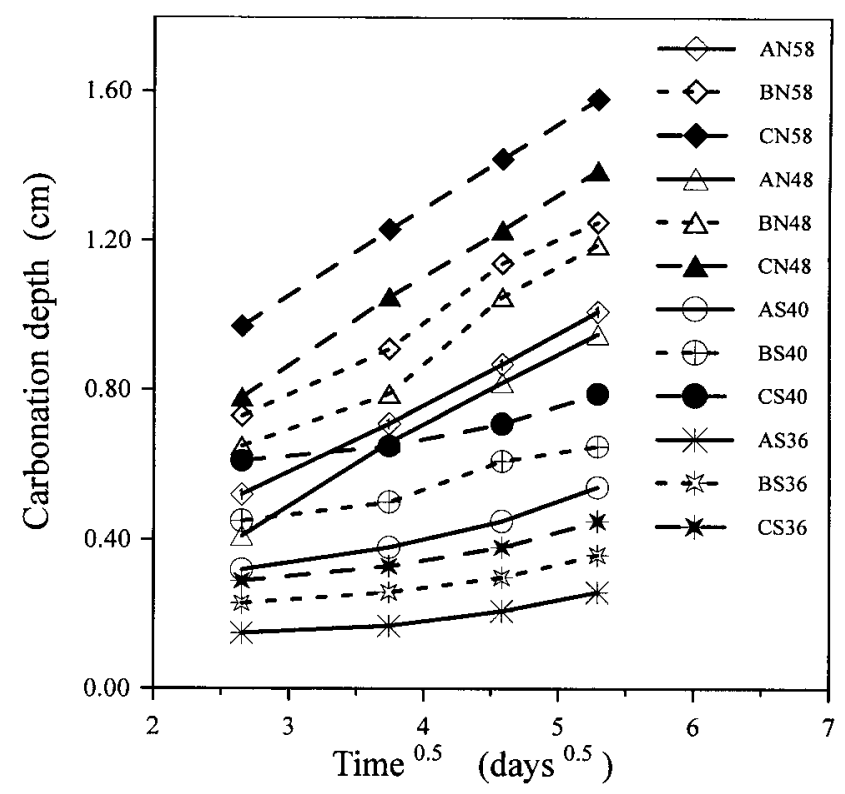

Fig. 1. Carbonation depth vs time for various concretes with different $\mathrm{CO}_{2}$ concentration. decreases with an increase in compressive strength. This approach appears to be very logical, since both carbonation and compressive strength are significantly controlled by the pore structure of concrete. Fattuhi and Wierig pointed out that the depth of carbonation decreases with increasing compressive strength for all types of concrete, but these relations depend on the type of cement and curing $[15,16]$. Test result has the similar

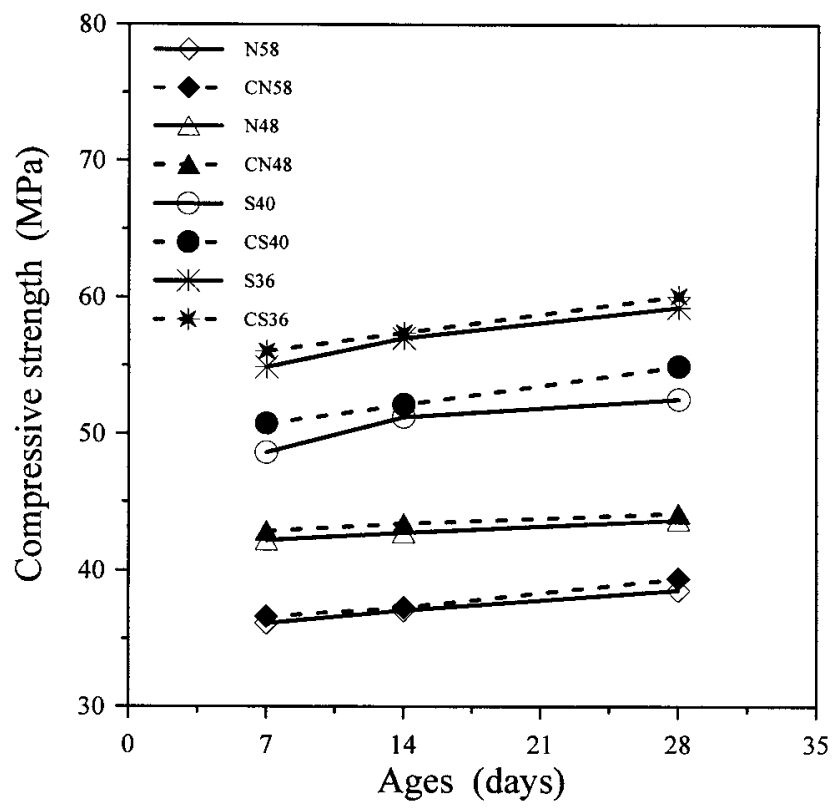

Fig. 2. Effect of ages on compressive strength for carbonated and noncarbonated concretes.

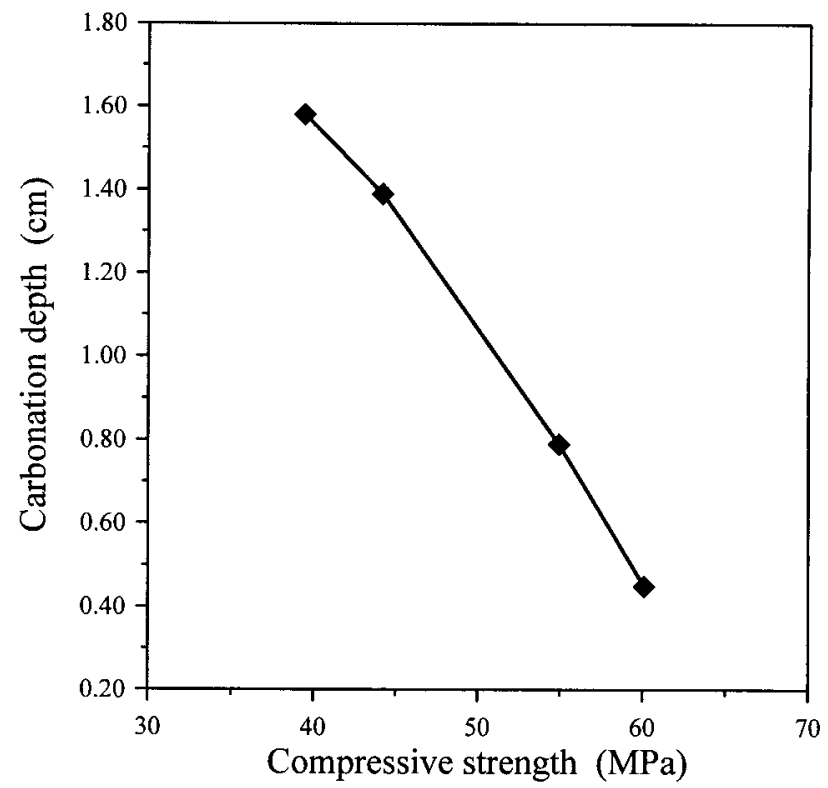

Fig. 3. Relationship between carbonation depth and compressive strength for various concretes. 
trend in comparison with the above-mentioned investigations.

\section{Splitting Strength}

The splitting strengths for concrete specimens with different water/binder ratios at the age of 7,14 and 28 days are shown in Figure 4. It is evident that the splitting strength of carbonated concretes slightly increases compared to the non-carbonated concretes and the higher water/binder ratio results in lower splitting strength. The trend of splitting strength development is similar to compressive strength development. Moreover, the increase of the splitting strength for all mixtures is very slight.

\section{Electrical Resistivity}

In general, the corrosion rate is related to corrosion current and electrical resistivity around steel bar. The corrosion rate of steel can be examined indirectly by measuring the electrical resistivity of concrete. Figure 5 shows the relationship between the resistivity of concretes with various water/binder ratios. It can be seen that the resistivity increases with an increase of carbonation time. The conductivity in concrete is due to the presence of water in the capillary pores, which contains dissolved salts and acts as an electrolyte. De Ceukelaire and Van Nieuwenburg indicated that there is a solid volume increase of around $11 \%$ in conversion of $\mathrm{Ca}(\mathrm{OH})_{2}$. to $\mathrm{CaCO}_{3}$, this involves an expansion of solid

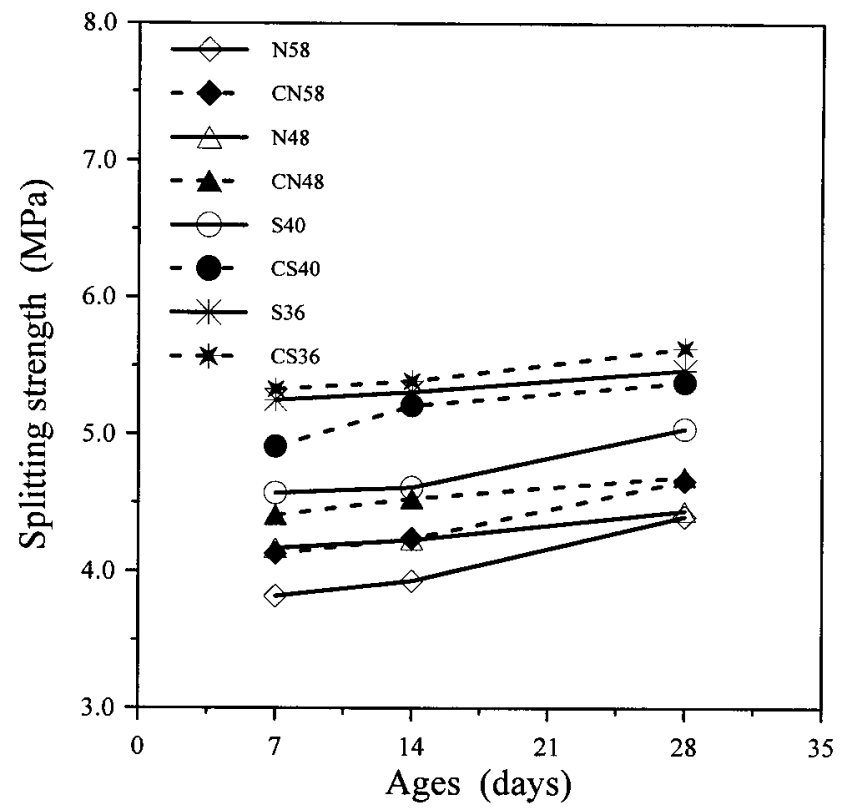

Fig. 4. Effect of ages on splitting strength for carbonated and non-carbonated concretes. volume in the paste and hense a reduction of porosity [17]. This would explain the increase of the resistivity of carbonated concrete by decreases of porosity and sorptivity. However, it must be pointed out that the resistivity of S36 concrete specimen is lower than that of S40 concrete specimen before the age of 14 days. The cement contents of S36 and S40 are $400 \mathrm{~kg} / \mathrm{m}^{3}$ and 200 $\mathrm{kg} / \mathrm{m}^{3}$ respectively. But the blast furnace slag contents of $S 36$ and $S 40$ are $125 \mathrm{~kg} / \mathrm{m}^{3}$ and $300 \mathrm{~kg} / \mathrm{m}^{3}$ respectively. It may be that blast furnace slag brings about the pozzolanic reaction and is more beneficial than cement to increase the cohesiveness of paste at early ages, thus increasing the resistivity of concrete.

\section{Rapid Chloride Penetration Test}

The RCPT is a convenient test method to evaluate concrete permeability. The relationship between the charge passed and the carbonation depth for four series of mixes is shown in Figure 6. It is clear that the total charge passed decreases with an increase of carbonation depth. The total charge passed of non-carbonated OPC is higher than 10,000 coulombs, but it decreases sharply after carbonation. However, the total charge passed of S40 and S36 decreases slightly because the total charge passed of non-carbonated SCC are 2,000 and 6,000 coulombs, respectively. Ihekwaba et al. demonstrated that a carbonation front was found to reduce chloride ion diffusion [1]. Some researchers have found that carbonation reduces chloride binding [18]. It indicates that carbonation improve the permeability of concrete due to the decreases of surface porosity after carbon-

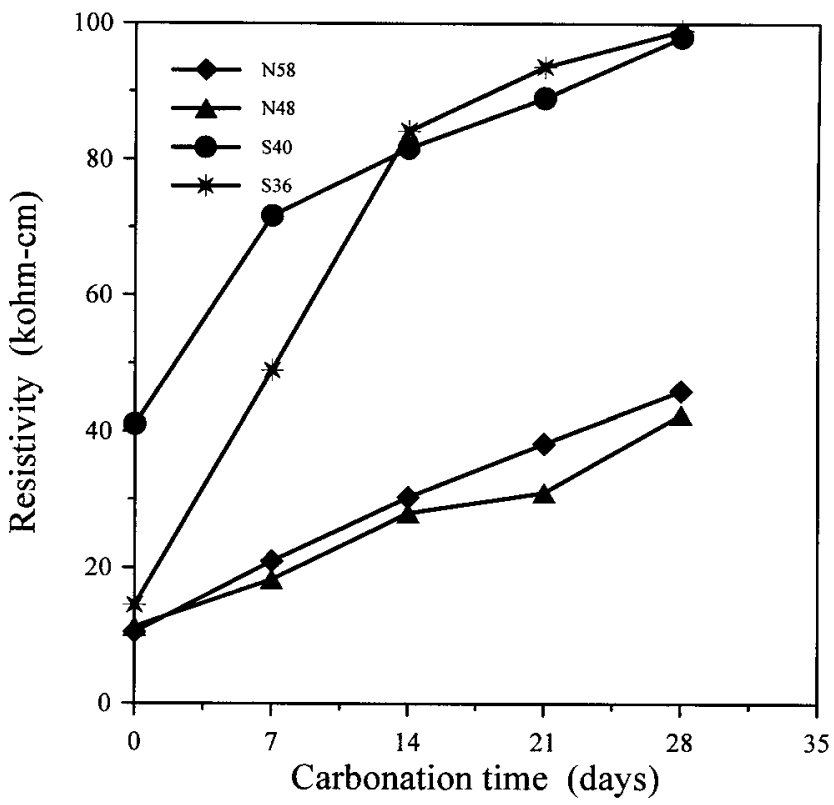

Fig. 5. Effect of carbonation time on resistivity for various concretes. 
ation and has a lower chloride ion penetration.

\section{Open Circuit Potential}

The corrosion reaction of reinforcing steel in concrete associated with the corrosion potential was defined in ASTM C876 [19]. The standard method gives criteria that the corrosion potential is more positive than $-120 \mathrm{mV}$ versus the SCE reference electrode $(-200 \mathrm{mV}$, $\mathrm{Cu} / \mathrm{CuSO}_{4}$ ), there is less than $10 \%$ probability to corrode, and the potential is more negative than $-270 \mathrm{mV}$ versus the SCE reference electrode $\left(-350 \mathrm{mV}, \mathrm{Cu} / \mathrm{CuSO}_{4}\right)$, there is greater than $90 \%$ probability to actively corrode. For the corrosion potential between $-120 \mathrm{mV}$ and -270 $\mathrm{mV}$, the corrosion reaction is considered uncertain. Open circuit potential measurements for specimens in $3.5 \% \mathrm{NaCl}$ solution and their variation with time are shown in Figure 7. It shows that, as time increased, all non-carbonated concretes-N58, N48, S40 and S36 are more than $90 \%$ probability to corrode as corrosion potential measured in $136,96,144$ and 168 hours respectively. In addition, all carbonated concretes are over $90 \%$ probability to corrode after carbonation. It may be the reduction of the $\mathrm{pH}$ value of the pore water causing chloride ion easily to diffuse or fill the concrete and corrosion may follow. That is, carbonation accelerates chloride-induced corrosion of reinforcement. The presence of a small mount of chlorides in carbonated concrete enhances the rate of corrosion induced by the low alkalinity of carbonated concrete [9].

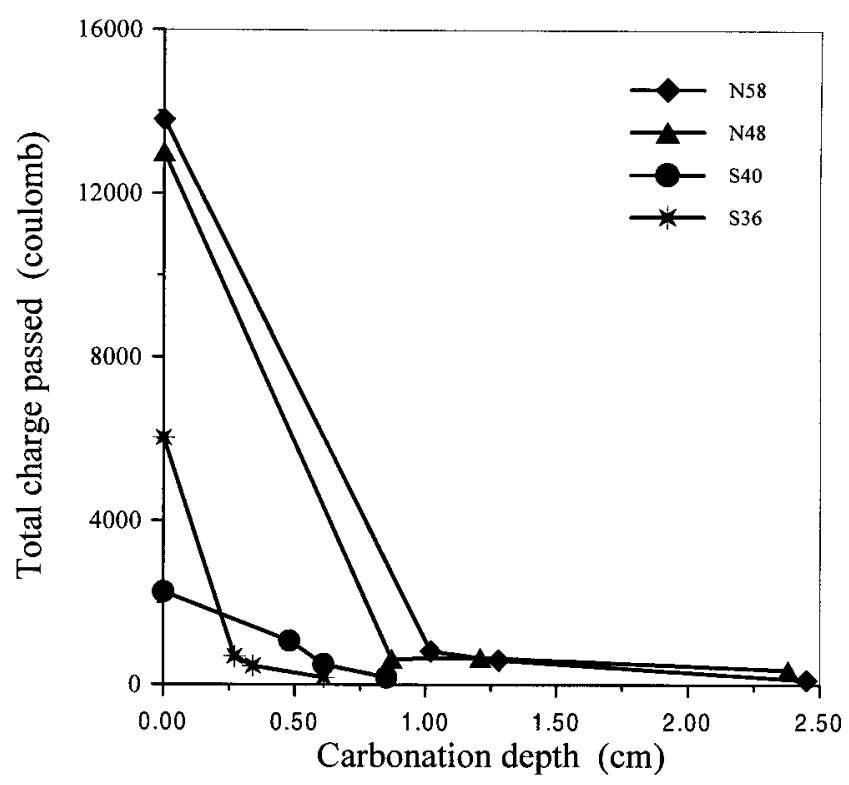

Fig. 6. Relationship between total charge passed and carbonation depth for various concretes.

\section{Alternative Current Impedance}

Figure 8 shows the relationship between the corrosion rate and exposure time. It shows that the corrosion rates of carbonated concretes are higher than those of non-carbonated concretes and SCC has a lower corrosion rate than OPC. It indicates carbonation increases the rate of corrosion of reinforcement. No significant difference was found in open circuit potential for SCC

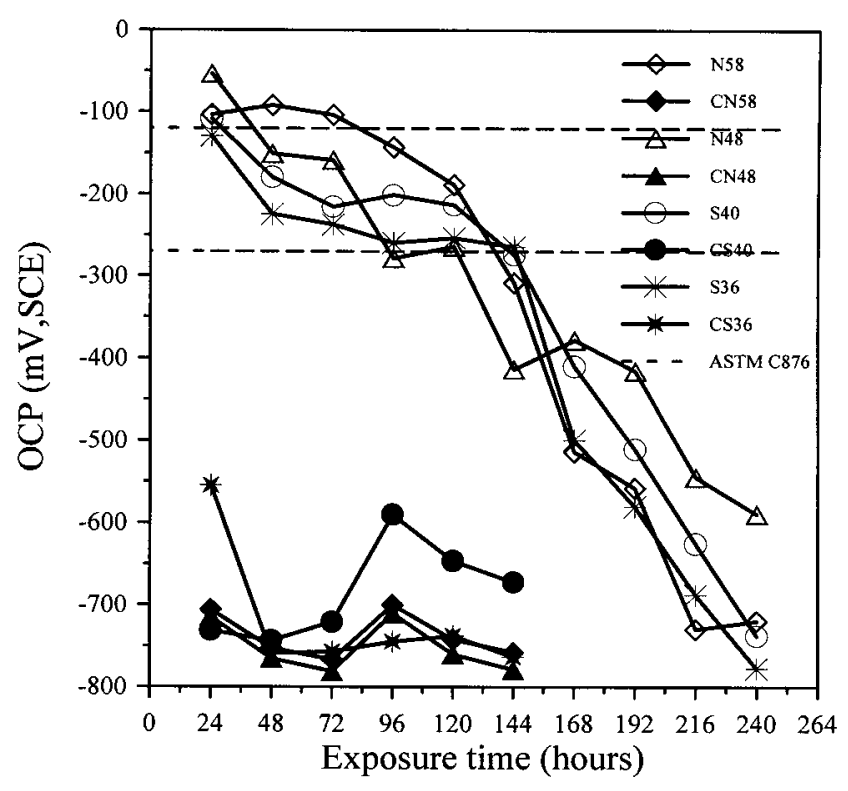

Fig. 7. Relationship between OCP and exposure time for carbonated and non-carbonated concretes.

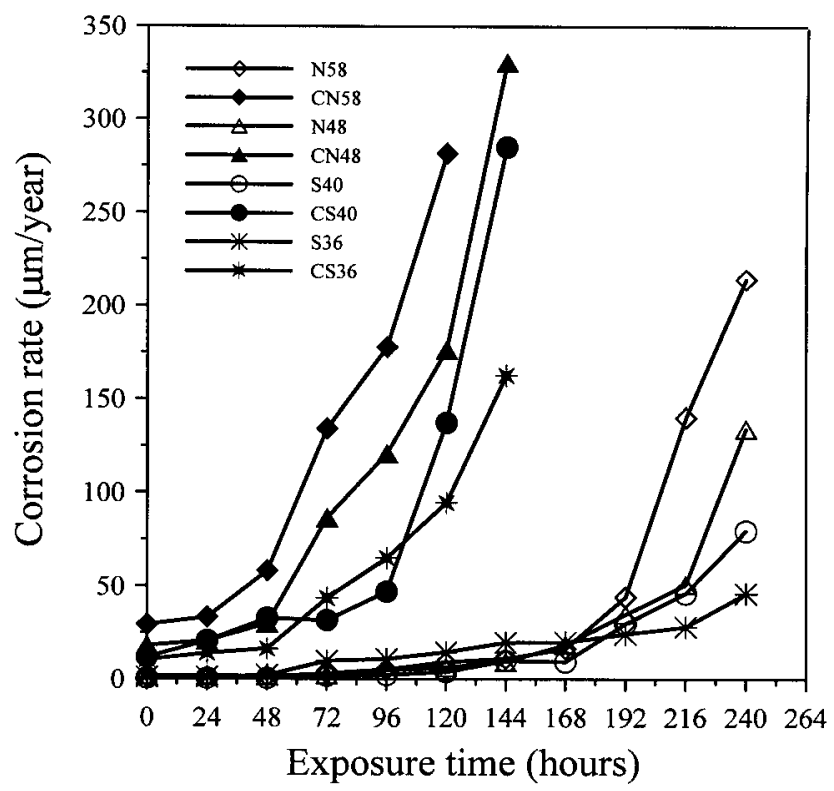

Fig. 8. Relationship between corrosion rate and exposure time for carbonated and non-carbonated concretes. 
and OPC. However, AC impedance test results have illustrated different corrosion rates among all mixtures.

\section{CONCLUSIONS}

Within the scope of this study, the following conclusions can be drawn.

(1) The carbonation depth increases with an increase in exposure time and higher $\mathrm{CO}_{2}$ concentration results in higher carbonation depth for all mixtures.

(2) The compressive strength and splitting strength of carbonated concrete at the age of 28 days are slightly higher than those of concrete without carbonation.

(3) The electrical resistivity of concrete increases with an increase in exposure time and the amount of charge passed significantly decreases with an increase in carbonation depth. However, carbonation of concrete enhances the rate of corrosion of reinforcement from the electrochemical corrosion test results.

\section{REFERENCES}

1. Ihekwaba N.M., Hope B.B. and Hanaaon C.M., "Carbonation and Electrochemical Chloride Extraction from Concrete," Cement and Concrete Research, Vol.26, No. 7, pp. 1095-1107 (1996).

2. Castro P., Moreno E.I. and Genesca J., "Influence of Marine Micro-climates on Carbonation of Reinforced Concrete Buildings," Cement and Concrete Research, Vol. 30, pp. 1565-1571 (2000).

3. Roper H. and Baweja D., "Carbonation-Chloride Interactions and their Influence on Corrosion Rates of Steel in Concrete," in: Malbotra V.M. (Ed.), Durability of Concrete, ACI SP-126, pp. 295-315 (1991).

4. Papadakis V.G., Fardis M.N. and Vayenas C.G., "Effect of Composition, Environmental Factors and Cementlime Motor Coating on Concrete Carbonation," Materials and Structures, Vol. 25, No. 149, pp. 293-304 (1992).

5. Roy S.K., Poh K.B. and Northwood D.O., "Durability of Concrete-Accelerated Carbonation and Weathering Studies," Cement and Concrete Research, Vol. 34, pp. 597-606 (1999).

6. Verbeck G.J., "Carbonation of Hydrated Portland Cement,” ASTM. Sp. Tech. Publ., No. 205, pp. 17-36
(1958).

7. Leber I. and Blakey F.A., "Some Effects of Carbon Dioxide on Motars and Concrete, J. Amer. Concr. Inst., Vol. 53, pp. 295-308 (1956).

8. Dias W.P.S., "Reduction of Concrete Sorptivity with Age through Carbonation," Cement and Concrete Research, Vol. 30, pp. 1255-1261 (2000).

9. Glass G.K., Page C.L. and Short N.R., "Factors Affecting the Corrosion Rate of Steel in Carbonated Motars," Corrosion Science, Vol. 32, No. 12, pp. 1283-1294 (1991).

10. V'eleva L. et al., "The Corrosion Performance of Steel and Reinforced Concrete in a Tropical Humid Climate. A Review," Corros Rev. Vol. 16, No. 3, pp. 235-284 (1998).

11. Papadakis V.G., Vayenas C.G. and Fardis M.N., "Fundamental Modeling and Experimental Investigation of Concrete Carbonation," ACI Materials Journal, JulyAug., pp. 363-373 (1991).

12. RILEM Committee CPC18, Measurement for Hardened Concrete Carbonated Depth, TC14-CPC (1988).

13. ASTM C1202-97, Test Method for Electrical Indication of Concrete Ability to Resist Chloride Ion Penetration (1997).

14. Ngala V.T. and Page C.L., "Effects of Carbonation on Pore Structure and Diffusional Properties of Hydrated Cement Pastes," Cement and Concrete Research, Vol. 27, No. 7, pp. 995-1007 (1997).

15. Fattuhi N.J., "Carbonation of Concrete as Affected by Mix Constituents and Initial Water Curing Period," Materials of Constructions, Vol. 19, No. 110, pp. 131136 (1986).

16. Wierig H.J., "Longtime studies on the Carbonation of Concrete Under Normal Outdoor Exposure," in Proceedings of the RILEM, Hannover University, pp. 239249 (1984).

17. De Ceukelaire L. and Van Nieuwenburg D., "Accelerated Carbonated of a Blast Furnace Cement Concrete," Cement and Concrete Research, Vol. 23, pp. 442-452 (1993).

18. Ho D.W.S. and Lewis R.K., "The Specification of Concrete for Reinforcement Protection-Performance Criteria and Compliance by Strength," Cement and Concrete Research, Vol. 18, No. 4, pp. 584-594 (1988).

19. ASTM C876-91, Standard Test Method for Half-Cell Potential of Uncoated Reinforcing Steel in Concrete, (1991). 


\title{
利用加速試驗法探討碳化對混凝土 力學性質與耐久性影響之研究
}

\author{
紀茂傑黄然
}

國立台灣海洋大學河海工程研究所

$$
\text { 楊仲家 }
$$

國立台灣海洋大學材料工程研究所

\section{摘 要}

本研究利用加速試驗法探討碳化對混凝土力學 性質與耐久性之影響。試驗項目包括混凝土碳化試 驗、抗壓強度試驗、䢃裂強度試驗、電阻試驗、快速 氯離子渗透試驗 $(\mathrm{RCPT})$ 及電化學腐蝕試驗等。研究 結果顯示碳化深度隨二氧化碳濃度提高而增加; 碳化 後之混凝土其抗壓強度、䢃裂強度、電阻係數皆提高 且電荷量下降。然而, 從電化學腐蝕量測結果卻發現 碳化後之混凝土其鋼筋腐蝕速率增加。

關鍵字：碳化、耐久性、加速試驗法。 